\title{
Urgences
}

\section{ici la douleur...}

Marie Bélisle

Numéro 15, octobre 1986

Épigraphiques

URI : https://id.erudit.org/iderudit/025351ar

DOI : https://doi.org/10.7202/025351ar

Aller au sommaire du numéro

Éditeur(s)

Urgences

\section{ISSN}

0226-9554 (imprimé)

1927-3924 (numérique)

Découvrir la revue

Citer ce document

Bélisle, M. (1986). ici la douleur... Urgences, (15), 93-93.

https://doi.org/10.7202/025351ar

Ce document est protégé par la loi sur le droit d'auteur. L'utilisation des services d'Érudit (y compris la reproduction) est assujettie à sa politique d'utilisation que vous pouvez consulter en ligne.

https://apropos.erudit.org/fr/usagers/politique-dutilisation/
Cet article est diffusé et préservé par Érudit.

Érudit est un consortium interuniversitaire sans but lucratif composé de l’Université de Montréal, l'Université Laval et l'Université du Québec à Montréal. Il a pour mission la promotion et la valorisation de la recherche. https://www.erudit.org/fr/ 


\title{
Marie Bélisle
}

\author{
Et le mal s'êtale, tant. \\ Comme une dalle est polie \\ Paul Valéry: "La caresse", dans Poésies
}

ici la douleur est fonction du degré d'incidence

et de la profondeur de la peau quand la morsure installe

par effraction l'état de manque à la surface même

épidermique qui dès lors s'attend à la caresse

infiniment et réclame le mâle et son cri et ses ongles

polis et ses dents sous la lèvre et son coeur et ses muscles ici

le mal est que le sperme échappé du sexe maintenant étalé

sur le drap où la cuisse se coille ne süffit pas et la main

arrêtée sur le plat de la fesse et les cheveux lissés

dans la sueur donc les corps

immobiles sur le carré du lit et la peau

malgré ça qui attend la caresse et réclame l'amant

et ses muscles encore et son coeur tant

et tant ici la douleur vient quand le mâle s'étend et

que ma langue passe sur ses dents polies ici

la douleur même vient de l'anesthésie comme le sommeil s'étale. 